Dhaka Univ. J. Biol. Sci. 31(1): 59-66, 2022 (January) DOI: https://doi.org/10.3329/dujbs.v31i1.57916

\title{
INFLUENCE OF ZINC AND VERMICOMPOST ON GROWTH, YIELD AND MINERAL NUTRIENT ACCUMULATION IN ONION (ALLIUM CEPA L.)
}

\author{
Shabnur ChOWDHURY*, Dibya ChaKRABARTY AND MK RAHMAN \\ Department of Soil, Water and Environment, University of Dhaka, Dhaka-1000, Bangladesh \\ Keywords: Growth and yield, Nutrient content, Onion, Zn, Vermicompost
}

\begin{abstract}
Effects of zinc, vermicompost and their joint effects on growth, yield and nutrient accumulation in the leaves and bulb of onion (Allium cepa L.) were examined. The experiment was conducted in a completely randomized design (CRD) replicated thrice with twelve treatments involving different doses of $\mathrm{Zn}$ and vermicompost and a control treatments. Growth parameters viz. leaf height, leaf number, leaf area, leaf area index, bulb height, bulb area and fresh and dry weight of leaf, stem, bulb and root were assessed. The highest leaf height (63.87 $\mathrm{cm})$, leaf number $(28)$, leaf area $\left(614.21 \mathrm{~cm}^{2}\right)$, fresh weight $(29.46 \mathrm{~g})$ and dry weight $(10.79 \mathrm{~g})$ at first harvest were found in $30 \%$ vermicompost $+70 \% \mathrm{Zn}$ application. The highest leaf height $(42.33 \mathrm{~cm})$, leaf number $(15)$, leaf area $(328.21$ $\left.\mathrm{cm}^{2}\right)$, bulb height $(5.67 \mathrm{~cm})$, bulb equatorial diameter $(5.67 \mathrm{~cm})$, fresh weight $(28.77 \mathrm{~g})$ and dry weight $(6.21 \mathrm{~g})$ were found at second harvest in $30 \%$ vermicompost $+70 \% \mathrm{Zn}$. The maximum nitrogen, phosphorus, potassium and Sulphur content of leaf were observed in $80 \%$ vermicompost $+20 \% \mathrm{Zn}$ application. The maximum nitrogen, phosphorus, potassium and sulphur content of bulb were observed in $60 \%$ vermicompost $+40 \% \mathrm{Zn}$ application. The overall best growth performance and nutrient accumulation were observed in $30 \%$ vermicompost $+70 \%$ Zn application.
\end{abstract}

\section{Introduction}

Onion (Allium cepa L.) belongs to the family Amaryllidaceae and is one of the most important monocotyledonous, cross-pollinated winter vegetable crop. Onion has its own distinctive flavor and is used in curry, soups, meat dishes, salads, and sandwiches, and is also cooked alone as a vegetable. Its pungency is due to the presence of a volatile oil (allyl propyl disulphide)(1) . One pound of onion contain protein $6 \mathrm{~g}$, fats $0.9 \mathrm{~g}$, carbohydrate 44 $\mathrm{g}$, calcium $137 \mathrm{mg}$, phosphorous $188 \mathrm{mg}$, iron $2.1 \mathrm{mg}$, thiamine $0.15 \mathrm{mg}$, riboflavin 0.1 $\mathrm{mg}$, niacin $0.6 \mathrm{mg}$ and ascorbic acid $38 \mathrm{mg}{ }^{(2)}$. During September to December onion price rises substantially because of its insufficient supply in Bangladesh. On the contrary, during January-March onion production increases and its price decreases. However, that increased production is not enough to satisfy the need of

*Author for correspondence: <shabnurchowdhury2@gmail.com>. 
onion to this enormous population of the country for a year. In Bangladesh, it is used almost in every cuisine that is why a huge amount of onion is needed every year. Therefore, it is really important to increase onion production in the country.

Zinc $(\mathrm{Zn})$ is a micronutrient which is required relatively in small amount for plant growth and development. Zinc is involved in the formation of chlorophyll and carbohydrate and is also involved in a diverse range of enzyme systems. The functional role of $\mathrm{Zn}$ includes auxin metabolism, influence on the activities of dehydrogenase and carbonic anhydrate enzymes, synthesis of cytochrome and stabilization of ribosomal fractions ${ }^{(3)}$. Application of $\mathrm{Zn}$ increased the growth and yield of onion ${ }^{(4)}$. More recently, it was revealed that organic manure along with mineral fertilizers were effective in increasing the growth, yield and quality contributing characters $(5,6)$. Soil organic matter content may help in improving the availability of micronutrients, including $\mathrm{Zn}$, by forming complexes with them ${ }^{(7)}$. Vermicompost is an organic manure which is important as a product of interactions between earthworm and microorganisms by degradation of organic waste( ${ }^{(8)}$. Vermicompost is very important to increase onion quality and yield. However, a limited number of work has been done on interactions of fertilizers particularly of vermicompost and $\mathrm{Zn}$ on growth of onion. Hence, an experiment was conducted to evaluate the effect of vermicompost and $\mathrm{Zn}$ on the growth of and mineral nutrient accumulation in onion.

\section{Materials and Methods}

Soil sample collection and characterization: In order to grow onion, soil (0-15 cm depth) was collected from Dhamrai, Savar and was air-dried, ground and sieved through $2 \mathrm{~mm}$ sieve. The soil had a $\mathrm{pH}$ of $7.45\left(1: 2.5 \mathrm{w} / \mathrm{N} \mathrm{H}_{2} \mathrm{O}\right)^{(9)}$, organic carbon $0.265 \%{ }^{(10)}$, available nitrogen $2.56 \%$ (Kjeldahl extraction)(11), available phosphorus $0.42 \%$ (blue color method using ascorbic acid)(12), exchangeable potassium $0.87 \%(13)$, available sulfur $0.28 \%$ (Turbidimetric method) ${ }^{(14)}$, sand $4.68 \%$, silt $69.45 \%$ and clay $26.01 \%$, textural class- silt loam ${ }^{(15)}$.

Pot experiment: A pot experiment ( $8 \mathrm{~kg}$ soil per pot) was carried out in the net house of the Department of Soil, Water and Environment, University of Dhaka from 15 November, 2020 to 14 January 2021. Eight kilograms of air-dried soil was taken in $10 \mathrm{~kg}$ capacity pot providing a drainage hole at the bottom. Twelve treatments with three replications applied were as: $\mathrm{T}_{1}$ : Control (without any $\mathrm{Zn}$ and vermicompost), $\mathrm{T}_{2}: 0 \%$ vermicompost and 100\% $\mathrm{Zn}$, T3: 10\% vermicompost and $90 \% \mathrm{Zn}, \mathrm{T}_{4}: 20 \%$ vermicompost and $80 \% \mathrm{Zn}$, T5: 30\% vermicompost and 70\% $\mathrm{Zn}$, T6: $40 \%$ vermicompost and $60 \% \mathrm{Zn}, \mathrm{T}_{7}$ : 50\% vermicompost and 50\% $\mathrm{Zn}, \mathrm{T}_{8}:$ 60\% vermicompost and $40 \% \mathrm{Zn}, \mathrm{T}_{9}: 70 \%$ vermicompost and $30 \% \mathrm{Zn}, \mathrm{T}_{10}: 80 \%$ vermicompost and $20 \% \mathrm{Zn}, \mathrm{T}_{11}: 90 \%$ vermicompost and $10 \% \mathrm{Zn}$, and $\mathrm{T}_{12:} 100 \%$ vermicompost and $0 \% \mathrm{Zn}$. 
Pots were arranged in a completely randomized design (CRD). Vermicompost was applied at the rate of 10 ton ha- ${ }^{-1}$ and $\mathrm{Zn}$ was applied at the rate of $3 \mathrm{~kg} \mathrm{ha}^{-1}$. The onion bulbs were collected from local market, Dhanmondi, Dhaka. Then, bulbs were cut into half and sowed in plastic cups. Ten days old one seedling of onion was transplanted in each pot. The pots were watered up to field capacity. Inter culture practices like weeding etc. were done when needed. The height of leaf, the number of leaf and leaf area were measured at 7 days intervals. The leaves were harvested for the first time at 35 days from transplanting. After the harvesting, leaves regrew from the bulb of onion and whole plants were harvested after 35 days from first harvest. Bulb length and bulb area were measured after second harvest.

Harvesting and analysis: Only leaves were harvested at first harvest and whole plants were harvested (including leaf, bulb and root) at second harvest, washed with tap water and distilled water and wrapped with soft tissue paper. Immediately after harvest, fresh weight of leaf, bulb and root were taken, air-dried in room temperature and oven-dried divided at $65^{\circ} \mathrm{C}$ in the laboratory for 72 hours. Leaf area indexes were measured through leaf area by pot area. Dry weight of the samples were measured, and ground with a mechanical grinder and stored in paper bags for chemical analysis. For nitrogen, $0.1 \mathrm{~g}$ of yield (leaf and bulb) sample was digested in a Kjeldahl digestion flask ${ }^{(8)}$, for phosphorus, potassium and sulfur $0.1 \mathrm{~g}$ of yield (leaf and bulb) was digested with nitric-perchloric acid. Phosphorus of the digest was determined by vanadomolybdophosphoric yellow color method at 470nm using spectrophotometer (model DR 5000)(9). Potassium of the digest was determined by using JENWAY flame photometer (model PFP 7)(13). Sulfur of the digest was determined by using turbidimetric method ${ }^{(14)}$. LSD test of the results was performed using Minitab, version 17.

\section{Results and Discussion}

Growth of the plants: Plant growth was assessed in terms of plant height, leaf number, leaf area, biomass production as leaf, bulb and root and nutrient content in leaf and bulb. The results of the height of leaf at 7 days intervals are presented in Table 1. Height values varied significantly $(\mathrm{p} \leq 0.5)$. The height of the leaves gradually increased. The highest height $(63.67 \mathrm{~cm})$ at first harvest and at second harvest $(42.33 \mathrm{~cm})$ were observed in the leaves growing in $\mathrm{T}_{5}$ treatment i.e. leaves growing with the application of $30 \%$ vermicompost and $70 \% \mathrm{Zn}$ after 30 days and 60 days of growth, respectively. The minimum value at first harvest was obtained in the control treatment $(22.0 \mathrm{~cm})$ and the value was $40.33 \mathrm{~cm}$ during second harvest.

The results of the leaf numbers per plant at 7 days intervals are presented in Table 2 . The leaf numbers increased day by day. But after 28 days, leaf numbers were not increasing. At 35 days, leaves were harvested. From the bulb, leaves were grown again and after 63days from transplanting, the leaf growth was too little. The leaf numbers of 
the plant varied significantly $(\mathrm{p} \leq 0.5)$. The minimum values of leaf number were recorded in control treatment and the maximum values of leaf number were recorded in application of $30 \%$ vermicompost and $70 \% \mathrm{Zn}$ after 30 days and 60 days of growth.

Table 1. Effects of zinc and vermicompost on the height of onion leaf.

\begin{tabular}{|c|c|c|c|c|c|c|c|c|c|c|}
\hline \multirow[t]{3}{*}{ Treatments } & \multicolumn{10}{|c|}{ Height of leaf in $\mathrm{cm}$ (Days after transplanting) } \\
\hline & \multicolumn{5}{|c|}{$1^{\text {st }}$ harvest } & \multicolumn{5}{|c|}{$2^{\text {nd }}$ harvest } \\
\hline & $7 \mathrm{~d}$ & $14 \mathrm{~d}$ & $21 d$ & $28 \mathrm{~d}$ & $35 d$ & $42 \mathrm{~d}$ & $49 \mathrm{~d}$ & $56 \mathrm{~d}$ & $63 \mathrm{~d}$ & $70 \mathrm{~d}$ \\
\hline $\mathrm{T}_{1}$ :Control & 4.33 & 4.33 & 13.67 & 27.00 & 40.33 & 2.33 & 5.67 & 7.00 & 17.00 & 22.00 \\
\hline $\mathrm{T}_{2}: 0 \% \mathrm{VC}+100 \% \mathrm{Zn}$ & 12.33 & 22.67 & 33.33 & 50.67 & 59.00 & 8.00 & 18.67 & 30.67 & 35.67 & 39.33 \\
\hline T3:10\%VC+90\%Zn & 10.33 & 23.00 & 36.67 & 51.00 & 61.00 & 8.00 & 18.67 & 31.33 & 34.33 & 38.33 \\
\hline $\mathrm{T}_{4}: 20 \% \mathrm{VC}: 80 \% \mathrm{Zn}$ & 7.33 & 21.33 & 35.00 & 52.33 & 61.33 & 7.67 & 18.00 & 31.67 & 34.67 & 40.33 \\
\hline $\mathrm{T}_{5}: 30 \% \mathrm{VC}+70 \% \mathrm{Zn}$ & 10.33 & 25.33 & 36.67 & 53.67 & 63.67 & 9.67 & 21.00 & 31.67 & 36.33 & 42.33 \\
\hline $\mathrm{T}_{6}: 40 \% \mathrm{VC}+60 \% \mathrm{Zn}$ & 10.67 & 21.33 & 35.00 & 52.67 & 61.00 & 7.67 & 18.67 & 31.67 & 35.00 & 40.33 \\
\hline T7:50\%VC+50\%Zn & 8.33 & 19.67 & 31.00 & 52.00 & 61.00 & 8.33 & 17.33 & 31.33 & 34.67 & 39.11 \\
\hline $\mathrm{T} 8: 60 \% \mathrm{VC}+40 \% \mathrm{Zn}$ & 5.33 & 24.00 & 33.33 & 51.00 & 61.33 & 7.67 & 17.67 & 31.67 & 35.33 & 41.00 \\
\hline $\mathrm{T}_{9}: 70 \% \mathrm{VC}+30 \% \mathrm{Zn}$ & 6.33 & 22.33 & 33.33 & 51.00 & 61.00 & 6.67 & 18.33 & 31.67 & 34.67 & 39.67 \\
\hline $\mathrm{T}_{10}: 80 \% \mathrm{VC}+20 \% \mathrm{Zn}$ & 8.00 & 22.67 & 35.00 & 51.00 & 59.67 & 6.67 & 17.67 & 31.33 & 33.33 & 41.00 \\
\hline $\mathrm{T}_{11}: 90 \% \mathrm{VC}+10 \% \mathrm{Zn}$ & 11.00 & 22.00 & 32.67 & 48.00 & 58.33 & 6.67 & 18.67 & 29.00 & 31.67 & 40.33 \\
\hline $\mathrm{T}_{12}: 100 \% \mathrm{VC}+0 \% \mathrm{Zn}$ & 9.67 & 21.67 & 35.00 & 49.00 & 58.67 & 8.00 & 18.33 & 30.33 & 32.67 & 38.00 \\
\hline LSD at $5 \%$ & 2.19 & 2.22 & 6.86 & 2.77 & 1.43 & 6.12 & 1.51 & 1.90 & 2.24 & 1.80 \\
\hline
\end{tabular}

Table 2. Effects of zinc and vermicompost on leaf number of onion plant.

\begin{tabular}{|c|c|c|c|c|c|c|c|c|c|c|}
\hline \multirow[t]{3}{*}{ Treatments } & \multicolumn{10}{|c|}{ Leaf number (Days after transplanting) } \\
\hline & \multicolumn{5}{|c|}{$1^{\text {st }}$ harvest } & \multicolumn{5}{|c|}{$2^{\text {nd }}$ harvest } \\
\hline & $7 \mathrm{~d}$ & $14 \mathrm{~d}$ & $21 \mathrm{~d}$ & $28 \mathrm{~d}$ & $35 d$ & $42 d$ & $49 \mathrm{~d}$ & $56 \mathrm{~d}$ & $63 d$ & $70 \mathrm{~d}$ \\
\hline T1:Control & 4 & 9 & 10 & 11 & 11 & 3 & 6 & 6 & 7 & 7 \\
\hline $\mathrm{T}_{2}: 0 \% \mathrm{VC}+100 \% \mathrm{Zn}$ & 6 & 10 & 21 & 22 & 22 & 5 & 11 & 11 & 12 & 13 \\
\hline T3:10\%VC+90\%Zn & 5 & 9 & 21 & 22 & 22 & 4 & 8 & 9 & 9 & 10 \\
\hline $\mathrm{T}_{4}: 20 \% \mathrm{VC}+80 \% \mathrm{Zn}$ & 6 & 9 & 21 & 22 & 22 & 5 & 9 & 10 & 11 & 12 \\
\hline $\mathrm{T}_{5}: 30 \% \mathrm{VC}+70 \% \mathrm{Zn}$ & 9 & 14 & 25 & 28 & 28 & 8 & 11 & 12 & 14 & 15 \\
\hline $\mathrm{T}_{6}: 40 \% \mathrm{VC}+60 \% \mathrm{Zn}$ & 6 & 13 & 26 & 26 & 26 & 5 & 9 & 9 & 11 & 12 \\
\hline T7:50\%VC+50\%Zn & 5 & 10 & 23 & 24 & 24 & 5 & 9 & 10 & 12 & 13 \\
\hline $\mathrm{T}_{8}: 60 \% \mathrm{VC}+40 \% \mathrm{Zn}$ & 7 & 10 & 23 & 23 & 23 & 6 & 9 & 10 & 11 & 12 \\
\hline $\mathrm{T}_{9}: 70 \% \mathrm{VC}+30 \% \mathrm{Zn}$ & 8 & 9 & 23 & 23 & 23 & 5 & 9 & 10 & 11 & 12 \\
\hline $\mathrm{T}_{10}: 80 \% \mathrm{VC}+20 \% \mathrm{Zn}$ & 7 & 12 & 24 & 25 & 25 & 6 & 10 & 10 & 11 & 12 \\
\hline $\mathrm{T}_{11}: 90 \% \mathrm{VC}+10 \% \mathrm{Zn}$ & 9 & 14 & 27 & 27 & 27 & 6 & 8 & 9 & 12 & 12 \\
\hline $\begin{array}{l}100 \% \text { vermicompost } \\
\text { and } 0 \% \mathrm{Zn}\end{array}$ & 6 & 11 & 24 & 25 & 25 & 6 & 10 & 10 & 11 & 12 \\
\hline LSD at $5 \%$ & 5.21 & 5.17 & 3.43 & 2.75 & 2.75 & 1.29 & 1.99 & 1.78 & 2.48 & 2.46 \\
\hline
\end{tabular}


The results of the leaf area per plant at 7 days intervals are presented in Table 3 . The leaf area gradually increased day by day up to 30 days. The leaf area of the plants varied significantly ( $\mathrm{p} \leq 0.5$ ) initially up to 30 days. The minimum values of leaf area were recorded in control treatment. The maximum values were recorded in application of $30 \%$ vermicompost $+70 \% \mathrm{Zn}$.

Table 3. Effects of zinc and vermicompost on leaf area of onion plants.

\begin{tabular}{|c|c|c|c|c|c|c|c|c|c|c|}
\hline \multirow{3}{*}{ Treatments } & \multicolumn{10}{|c|}{ Leaf area $\left(\mathrm{cm}^{2}\right)($ Days after transplanting) } \\
\hline & \multicolumn{4}{|c|}{$1^{\text {st }}$ harvest } & \multicolumn{6}{|c|}{$2^{\text {nd }}$ harvest } \\
\hline & $7 \mathrm{~d}$ & $14 \mathrm{~d}$ & $21 \mathrm{~d}$ & $28 \mathrm{~d}$ & $35 d$ & $42 \mathrm{~d}$ & $49 \mathrm{~d}$ & $56 \mathrm{~d}$ & $63 d$ & $70 d$ \\
\hline $\mathrm{T}_{1}$ :Control & 15.17 & 33.49 & 112.12 & 268.61 & 394.24 & 8.89 & 28.01 & 44.67 & 113.09 & 174.92 \\
\hline $\mathrm{T}_{2}: 0 \% \mathrm{VC}+100 \% \mathrm{Zn}$ & 40.31 & 148.72 & 260.35 & 491.69 & 570.20 & 26.70 & 85.19 & 178.52 & 230.40 & 305.59 \\
\hline $\mathrm{T}_{3}: 10 \% \mathrm{VC}+90 \% \mathrm{Zn}$ & 34.02 & 150.80 & 285.53 & 494.80 & 589.05 & 26.70 & 85.19 & 182.26 & 221.99 & 298.05 \\
\hline $\mathrm{T}_{4}: 20 \% \mathrm{VC}+80 \% \mathrm{Zn}$ & 24.60 & 140.30 & 272.94 & 507.34 & 592.16 & 25.67 & 82.25 & 184.18 & 224.12 & 313.13 \\
\hline $\mathrm{T}_{5}: 30 \% \mathrm{VC}+70 \% \mathrm{Zn}$ & 10.33 & 165.44 & 285.53 & 519.97 & 614.21 & 31.95 & 95.44 & 184.18 & 234.55 & 328.21 \\
\hline $\mathrm{T}_{6}: 40 \% \mathrm{VC}+60 \% \mathrm{Zn}$ & 35.09 & 140.30 & 272.94 & 510.54 & 589.05 & 25.67 & 85.19 & 184.18 & 226.20 & 313.13 \\
\hline T7:50\%VC+50\%Zn & 27.74 & 129.87 & 242.78 & 504.23 & 589.05 & 27.74 & 79.30 & 182.26 & 224.12 & 303.93 \\
\hline $\mathrm{T} 8: 60 \% \mathrm{VC}+40 \% \mathrm{Zn}$ & 18.32 & 157.08 & 260.35 & 494.80 & 592.16 & 25.67 & 80.80 & 184.18 & 228.27 & 318.18 \\
\hline $\mathrm{T}_{9}: 70 \% \mathrm{VC}+30 \% \mathrm{Zn}$ & 21.46 & 146.59 & 260.35 & 494.80 & 589.05 & 22.53 & 83.70 & 184.18 & 224.12 & 308.15 \\
\hline $\mathrm{T}_{10}: 80 \% \mathrm{VC}+20 \% \mathrm{Zn}$ & 26.70 & 148.72 & 272.94 & 494.80 & 576.52 & 22.53 & 80.80 & 182.26 & 215.70 & 318.18 \\
\hline $\mathrm{T}_{11}: 90 \% \mathrm{VC}+10 \% \mathrm{Zn}$ & 36.13 & 144.51 & 255.37 & 466.53 & 563.89 & 22.53 & 85.19 & 169.08 & 205.27 & 313.13 \\
\hline $\mathrm{T}_{12}: 100 \% \mathrm{VC}+0 \% \mathrm{Zn}$ & 31.95 & 142.44 & 272.94 & 475.92 & 567.09 & 26.13 & 83.70 & 176.60 & 211.56 & 295.56 \\
\hline LSD 5\% & 6.89 & 13.94 & 51.75 & 26.1 & 13.47 & 19.22 & 6.63 & 10.75 & 14.09 & 13.57 \\
\hline
\end{tabular}

Maximum bulb height $(5.67 \mathrm{~cm})$ and bulb equatorial diameter $(5.67 \mathrm{~cm})$ were recorded in application of $30 \%$ vermicompost $+70 \%$. The minimum values were observed in the control treatment. The values varied significantly $(\mathrm{p} \leq 0.5)$. Zinc is also essential for bulb formation, therefore, early application is important. If zinc is low when bulbs are forming, yields will be significantly reduced ${ }^{(16)}$.

Fresh and dry matter yield: The fresh and dry weights of leaf, bulb and root are presented in Table 4 . The values for leaf and root varied significantly $(p \leq 0.05)$ for both fresh and dry weights except dry weight of leaf at first harvest. The highest yields were achieved in 30\% vermicompost $+70 \% \mathrm{Zn}$ application. The fresh yield was $29.46 \mathrm{~g} / \mathrm{plant}$ and dry weight values was $10.79 \mathrm{~g}$ /plant after first harvest (Table 4). The highest values were recorded for fresh weights of leaf, bulb and root were 28.77, 13.58 and $8.46 \mathrm{~g} /$ plant and for dry weights were 6.21, 5.84 and $2.98 \mathrm{~g} / \mathrm{plant}$ in the treatment of $30 \%$ vermicompost and $70 \% \mathrm{Zn}$, respectively. The minimum values for fresh weights and for dry weights for leaf, bulb and root were recorded with the control treatment. The maximum total yields of fresh and dry weights were 50.81 and $15.03 \mathrm{~g} /$ plant, respectively 
recorded with the same treatment. There is evidence that micronutrients such as $\mathrm{Zn}$ increased the dry yield of onion plants ${ }^{(17)}$.

Table 4. Effects of zinc and vermicompost on fresh and dry weight of onion plants.

\begin{tabular}{|c|c|c|c|c|c|c|c|c|c|c|}
\hline \multirow{3}{*}{ Treatments } & \multicolumn{2}{|c|}{$1^{\text {st }}$ harvest } & \multicolumn{8}{|c|}{$2^{\text {nd }}$ harvest } \\
\hline & \multirow{2}{*}{$\begin{array}{l}\begin{array}{l}\text { Fresh } \\
\text { wt. }(g)\end{array} \\
\text { Leaf }\end{array}$} & \multirow{2}{*}{$\begin{array}{l}\text { Dry wt. } \\
(\mathrm{g})\end{array}$} & \multicolumn{5}{|c|}{ Fresh weight (g) } & \multicolumn{3}{|c|}{ Dry weight (g) } \\
\hline & & & Leaf & Bulb & Root & Total & Leaf & Bulb & Root & Total \\
\hline $\mathrm{T}_{1}$ :Control & 13.12 & 3.98 & 10.39 & 5.72 & 3.69 & 19.80 & 2.92 & 2.67 & 2.49 & 8.08 \\
\hline $\mathrm{T}_{2}: 0 \% \mathrm{VC}+100 \% \mathrm{Zn}$ & 26.20 & 6.31 & 16.78 & 9.54 & 6.43 & 32.75 & 5.92 & 5.18 & 2.77 & 13.87 \\
\hline $\mathrm{T}_{3}: 10 \% \mathrm{VC}+90 \% \mathrm{Zn}$ & 22.05 & 5.67 & 12.61 & 11.38 & 7.94 & 48.09 & 4.83 & 4.59 & 2.83 & 12.25 \\
\hline $\mathrm{T}_{4}: 20 \% \mathrm{VC}: 80 \% \mathrm{Zn}$ & 27.93 & 8.94 & 15.23 & 9.22 & 7.16 & 31.61 & 4.21 & 4.27 & 2.83 & 11.31 \\
\hline $\mathrm{T}_{5}: 30 \% \mathrm{VC}+70 \% \mathrm{Zn}$ & 29.46 & 10.79 & 28.77 & 13.58 & 8.46 & 50.81 & 6.21 & 5.84 & 2.98 & 15.03 \\
\hline $\mathrm{T}_{6}: 40 \% \mathrm{VC}+60 \% \mathrm{Zn}$ & 25.72 & 5.32 & 24.21 & 8.31 & 6.94 & 46.25 & 4.76 & 5.29 & 2.96 & 13.01 \\
\hline T7:50\%VC+50\%Zn & 20.18 & 3.73 & 22.37 & 8.93 & 4.62 & 35.92 & 5.31 & 5.76 & 2.70 & 13.77 \\
\hline $\mathrm{T} 8: 60 \% \mathrm{VC}+40 \% \mathrm{Zn}$ & 24.99 & 5.62 & 24.57 & 12.61 & 7.81 & 44.99 & 6.03 & 4.61 & 2.84 & 14.89 \\
\hline $\mathrm{T}_{9}: 70 \% \mathrm{VC}+30 \% \mathrm{Zn}$ & 25.84 & 5.97 & 18.47 & 8.68 & 7.67 & 34.82 & 5.32 & 5.19 & 2.66 & 13.17 \\
\hline $\mathrm{T}_{10}: 80 \% \mathrm{VC}+20 \% \mathrm{Zn}$ & 21.10 & 4.89 & 13.91 & 9.03 & 6.61 & 29.55 & 5.40 & 4.17 & 2.75 & 12.32 \\
\hline $\mathrm{T}_{11}: 90 \% \mathrm{VC}+10 \% \mathrm{Zn}$ & 19.83 & 4.63 & 19.27 & 9.91 & 7.60 & 36.78 & 5.29 & 4.33 & 2.54 & 12.16 \\
\hline $\mathrm{T}_{12}: 100 \% \mathrm{VC}+0 \% \mathrm{Zn}$ & 21.30 & 4.91 & 12.98 & 9.55 & 7.35 & 29.88 & 4.42 & 4.78 & 2.61 & 11.81 \\
\hline LSD 5\% & 17.46 & NS & 8.24 & 2.84 & 2.28 & - & 1.09 & 0.87 & 0.24 & - \\
\hline
\end{tabular}

Nutrient content in leaf: Mean values of total macro nutrient concentrations in the leaves and bulbs of onion are presented in Table 5 The maximum amounts of total nitrogen $(10.91 \%)$, total phosphorus $(0.66 \%)$, total potassium $(1.46 \%)$ and total sulphur $(0.87 \%)$ in leaf were observed in application of $80 \%$ vermicompost $+20 \% \mathrm{Zn}$. The maximum amounts of total nitrogen $(1.94 \%)$, total phosphorus $(1.57 \%)$, total potassium $(1.49 \%)$ and total sulphur $(0.35 \%)$ in bulb were also observed in application of $60 \%$ vermicompost $+40 \% \mathrm{Zn}$. The minimum results were recorded in control treatment.

The experiment reported here is primarily concerned with the growth response, both fresh and dry matter yield and nutrient accumulation of onion (A.cepa ). Plants are influenced by different treatments of $\mathrm{Zn}$ and vermicompost manure. It revealed that different growth parameters have been influenced by the combined application (inorganic + organic) fertilizers. Combined application of fertilizers increased the growth parameters, but the treatment $\mathrm{T}_{5}(30 \%$ vermicompost and $70 \% \mathrm{Zn}$ ) has shown the best result than the other treatments in growth response and fresh and dry matter yield. The $\mathrm{T}_{10}(80 \%$ vermicompost and $20 \% \mathrm{Zn})$ and $\mathrm{T}_{8}(60 \%$ vermicompost and $40 \% \mathrm{Zn})$ have shown the best result in nutrient accumulation in leaf and bulb respectively. This signifies that fertilizers need to be used carefully according to soil health and crop need. 
Table 5. Concentration (\%) of nitrogen, phosphorus, potassium and sulfur in the leaf and bulb of onion plants.

\begin{tabular}{|c|c|c|c|c|c|c|c|c|}
\hline \multirow[t]{2}{*}{ Treatment } & \multicolumn{4}{|c|}{ Leaf } & \multicolumn{4}{|c|}{ Bulb } \\
\hline & Nitrogen & Sulfur & Potassium & $\begin{array}{l}\text { Phos- } \\
\text { phorus }\end{array}$ & Nitrogen & Sulfur & Potassium & $\begin{array}{l}\text { Phos- } \\
\text { phorus }\end{array}$ \\
\hline $\mathrm{T}_{1}:$ Control & 3.19 & 0.02 & 0.04 & 0.03 & 0.45 & 0.05 & 0.01 & 0.06 \\
\hline $\mathrm{T}_{2}: 0 \% \mathrm{VC}+100 \mathrm{Zn}$ & 3.93 & 0.38 & 1.29 & 0.92 & 1.48 & 0.33 & 0.21 & 0.92 \\
\hline $\mathrm{T}_{3}: 10 \% \mathrm{VC}+90 \% \mathrm{Zn}$ & 5.51 & 0.06 & 0.87 & 0.40 & 1.78 & 0.19 & 0.85 & 1.55 \\
\hline $\mathrm{T}_{4}: 20 \% \mathrm{VC}+80 \% \mathrm{Zn}$ & 4.23 & 0.41 & 0.13 & 0.30 & 1.83 & 0.32 & 0.72 & 1.40 \\
\hline $\mathrm{T}_{5}: 30 \% \mathrm{VC}+70 \% \mathrm{Zn}$ & 5.94 & 0.42 & 0.54 & 0.55 & 1.53 & 0.32 & 0.06 & 0.37 \\
\hline $\mathrm{T}_{6}: 40 \% \mathrm{VC}+60 \% \mathrm{Zn}$ & 3.93 & 0.52 & 1.34 & 0.63 & 0.67 & 0.13 & 0.04 & 0.16 \\
\hline T7:50\%VC+50\%Zn & 4.53 & 0.40 & 0.75 & 0.52 & 1.24 & 0.21 & 0.04 & 0.67 \\
\hline T8:60\%VC+40\%Zn & 5.27 & 0.48 & 1.39 & 0.48 & 1.94 & 0.35 & 1.49 & 1.57 \\
\hline T9:70\%VC+30\%Zn & 8.91 & 0.03 & 1.07 & 0.61 & 0.97 & 0.20 & 0.04 & 0.32 \\
\hline $\mathrm{T}_{10}: 80 \% \mathrm{VC}+20 \% \mathrm{Zn}$ & 10.91 & 0.87 & 1.46 & 0.66 & 1.19 & 0.24 & 0.06 & 0.29 \\
\hline $\mathrm{T}_{11}: 90 \% \mathrm{VC}+10 \% \mathrm{Zn}$ & 3.21 & 0.40 & 1.27 & 0.63 & 1.86 & 0.16 & 0.43 & 0.61 \\
\hline $\mathrm{T}_{12}: 100 \% \mathrm{VC}+0 \% \mathrm{Zn}$ & 8.53 & 0.03 & 1.34 & 0.95 & 2.15 & 0.22 & 0.04 & 0.43 \\
\hline LSD at $5 \%$ & 0.01 & 0.01 & 0.01 & 0.01 & 0.01 & 0.01 & 0.01 & 0.01 \\
\hline
\end{tabular}

Balanced fertilizer application is essential for the vegetative growth and, thus, for producing crops with top quality and high yields especially on soils that are cultivated continuously ${ }^{(18,19)}$. If it is done, more positive interactive effects of inorganic and organic fertilizers to get best growth of crops can be possible.

\section{References}

1. Malik MN 1994. Bulb crops, Onion. In: Horticulture. National Book Foundation Islamabad Pakistan. pp. 500-501.

2. Thomson HC and WC Kelly 1982. Bulb Crops Vegetable Crops. Tata McGraw-Hill publishing company Limited, New York. Reprinted at Pakistan printing Works, Lahore. pp. 61.

3. Tisdale SL, WL Nelson, and JD Beaten 1984. Zinc. In: Soil Fertility and Fertilizers. Macmillan Publishing Company, New York. $4^{\text {th }}$ edn. pp. 382-391.

4. Phor SK, UC Pandey and U Verma 1995. Effects of zinc on the growth and yield of garlic (Allium sativum L). Crop Research 9: 286-291.

5. Gupta RP, VP Sharma, DK Singh and KJ Srivastava 1999. Effect of organic manures and inorganic fertilizers on growth, yield and quality of onion variety Agrifound Dark Red. Newsletter National Horticultural Research and Development Foundation 19(2-3): 7-10.

6. Abbey L 2000. Effect of poultry manure and post-production application of fungicide on the shelf-life of onion cv. Bawku Red. Crop Research Hisar. 20 (1): 87-92.

7. Tagwira F, M Piha and L Mugwira 1992. Effect of $\mathrm{pH}$, and phosphorus and organic matter contents on zinc availability and distribution in two Zimbabwean soils. Community of Soil Science Plant Analysis 23: 1485-1500 
8. Arancon NQ, CA Edwards, P Bierman, JD Metzger and C Lucht 2005. Effects of vermicomposts produced from cattle manure, food waste and paper waste on the growth and yield of peppers in the field. Pedobiologia 49: 297-306.

9. Jackson ML 1965. Soil Chemical Analysis. Prentice- Hall, Inc.,Englewood Cliffs, NJ. USA. pp. 498.

10. Walkley A and IA Black 1934. An examination of the Degtjareff method for determining soil organic matter and a proposed modification of the chromic acid titration method. Soil Sci. 37: $29-38$

11. Marr IL and MS Cresser 1983. The lithosphere. In: Environmental Chemical Analysis. Blackie and Son, UK. pp. 155-182.

12. Olsen SR, CV Cole, FS Watanabe and LA Dean 1954. Estimation of available phosphorus in soils by extraction with sodium bicarbonate.US Department of Agriculture Circ. No. 939.

13. Pratt PF 1965. Potassium. In: C. A. Black (ed.). Methods of Soil Analysis. Part 2. American Society of Agronomy, Inc., Madison, Wisconsin, USA. pp. 1022-1030.

14. Bardsley CE and JD Lancaster 1965. Sulfur. In: C. A. Black (ed.). Methods of Soil Analysis. Part 2. American Society of Agronomy, Inc., Madison, Wisconsin, USA. pp. 1102- 1114.

15. Bouyoucos GT 1962. Hydrometer method improved for making particle size analysis of soils. Agron. J. 54: 464- 465.

16. Kumar M, DK Das and DK Kumar 2000. Effect of zinc and sulfur application on their availability in soil in relation to yield and nutrition of onion (Allium cepa L.). Madras Agricultural Journal 84 (7): 382-384.

17. Sliman ZT , MA Abdelhakim and AA Omran 1999. Response of onion to foliar application of some micronutrients. Egyptian J. Agric. Res. 77(3): 983-993.

18. Chintala R, LM McDonald and WB Bryan 2012a. Effect of soil water and nutrients on productivity of Kentucky bluegrass systems in acidic soils. Journal of Plant Nutrition 35: 288-303.

19. Chintala R, LM McDonald and WB Bryan 2012b. Optimization of water potential and nutrient levels for Kentucky bluegrass-white clover mixture on acidic soils. Biotechnology, Agronomy, Society and Environment 16: 167-177.

(Manuscript received on 12 August, 2021; accepted on 25 November, 2021) 